\title{
FORENSIK DIGITAL METODE REGEX (REGULAR EXPRESSION) DARI GRAB GOOGLE SEARCH API DALAM PROSES PELACAKAN TERHADAP KEJAHATAN ONLINE
}

\author{
Nur Rochmah Dyah Puji Astuti, Fiftin Noviyanto, Dewi Soyusiawati \\ Teknik Informatika, Tegnologi Industri, Universitas Ahmad Dahlan \\ Jl. Prof. DR. Soepomo Sh, Warungboto, Umbulharjo, Daerah Istimewa Yogyakarta, Indonesia,55164 \\ rochmahdyah@tif.uad.ac.id, fiftin.novitanto@tif.uad.ac.id, dewi.soyusiawaty@tif.uad.ac.id
}

\begin{abstract}
Abstrak- Penipuan yang dilakukan melalui website dan blog merupakan kejahatan online yang marak terjadi. Saat ini proses pelaporan masyarakat masih dilakukan dengan mengisi form laporan, sedangkan untuk proses pelacakan dari data laporan masih menggunakan cara mengunjungi website secara satupersatu, sehingga tidak efektif, maka dilakukan penelitian yang menghasilkan proses dan alur sistem pelacakan kejahatan online dengan memanfaatkan Metode Regex (Regular Expression) Dari Grab Google Search Api. Proses pelacakan menggunakan metode RegEx (Regular Expression) yang merupakan suatu notasi fleksibel dan ringkas untuk mencari dan menggantikan pola teks. Metode pengumpulan data dengan metode observasi dan wawancara. Tahap analisa proses pelacakan dilanjukan perancangan alur proses pelaporan dan perancangan alur sistem. Dirancang Prototyping halaman pelaporan yang menggunakan metode regex. Hasil penelitan berupa alur sistem pelacakan dengan menerapkan metode RegEx dari grab google search untuk melacak website dan blog dengan keyword berupa alamat website dan nomor handphone. Alur sistem baru lebih mengefektifkan sisi waktu proses pencarian situs penipuan yang di-index oleh google. Masyarakat dapat mengetahui antara website terpercaya dengan website yang dibuat oleh penipu, sehingga masyarakat akan lebih berhati-hati terhadap penipuan.
\end{abstract}

Keywords-Metode Regex (Regular Expression), Grab Google Search Api, proses pelacakan.

\begin{abstract}
Fraud carried out through websites and blogs is a widespread online crime. At present the community reporting process is still done by filling out the report form, while for the tracking process of the report data still using the website one by one, so that it is not effective, research is carried out which results in the process and flow of online crime tracking system using the Regex Method ( Regular Expression) From Google Search Fire Grab. The tracking process uses the RegEx (Regular Expression) method which is a flexible and concise notation for finding and replacing text patterns. Data collection methods with observation and interview methods. The analysis phase of the tracking process is carried out by designing the reporting process flow and designing the system flow. Designed Prototyping reporting page that uses the regex method. The research results in the form of a tracking system by applying the RegEx method from grab google search to track websites and blogs with keywords in the form of website addresses and cellphone numbers. The flow of the new system more effectively streamlines the search process for fraudulent sites indexed by Google. People can find out between trusted websites and websites created by fraudsters, so that people will be more careful about fraud.
\end{abstract}

Keywords— Regex Method (Regular Expression), Google Search Fire Grab, tracking process.

\section{PENDAHULUAN}

Cybercrime merupakan kejahatan dengan menggunakan komputer atau jaringan computer/internet sebagai alat, sarana atau tempat melakukan kejahatan. Masalah cybercrime mayoritas terjadi di kota-kota besar seperti Jakarta, bandung, Yogyakarta dan Surabaya, dimana kejahatan dunia maya yang terjadi diIndonesia menurut data Bareskrim Polri mencakup ratusan tindak pidana yang menimbulkan kerugian materi yang cukup besar.
Penipuan dengan menggunakan website dan blog semakin meningkat, dalam sehari laporan yang diterima oleh Kepala Satuan Reserse Kriminal Polres Jakarta Selatan mencapai 3-4 laporan di setiap harinya (Sutji Decilya, Tempo. 2013). Maraknya penipuan yang dilakukan melalui website dan blog merupakan kejahatan online yang sangat merugikan pihak disebabkan sasaran penipuan adalah masyarakat yang masih pemula dalam menggunakan teknologi informasi, yang masih kurang memahami cara mengidentifikasi ciri-ciri dari infromasi penipuan tersebut. Karena biasanya penipu mengunaan 
alamat website palsu menggunakan nama yang mirip dengan situs resmi sebuah perusahaan, tidak hanya menggunakan nama yang mirip dari segi desain website juga dibuat sama dengan tampilan website resminya. Dengan semakin meningkatnya korban penipuan menjadikan keinginan masyarakat untuk melaporkan kejahatan online atau cyber crime semakin meningkat (Sutji Decilya, Tempo. 2013).

Kendala yang dihadapi oleh Direktorat Reserse Kriminal Khusus DIY dalam pengungkapan tindak pidana penipuan melalui internet adalah personil kepolisian yang menangani tindak pidana melalui internet masih kurang baik secara kualitas yaitu pendidikan atau pengetahuan anggota kepolisian dalam bidang IT yang masih kurang, dan dari segi sarana dan prasana, sehingga menyebabkan proses penanganan tindak pidana penipuan melalui internet masih kurang berjalan dengan baik. Pengecekan yang dilakukan oleh dinas kepolisian dari data laporan yang dikirim oleh masyarakat yang terkena penipuan masih dilakukan dengan menggunakan cara mengunjungi website secara satu-persatu, sehingga cara tersebut tidak efektif dikarenakan membutuhkan waktu yang lama mulai dari proses pencarian hingga mendeteksi penipuannya. Selain itu, pelacakan dengan mengunakan web browser biasa akan mengalami kendala karena terkadang informasi yang dicari menggunakan kata kunci tampil diurutan kesekian dari halaman mesin pencari sehingga sangat menyulitkan pencarian, hal tersebut disebabkan karena adanya keterkaitan SEO (Search Engine Optimization) yang secara sistematis bertujuan untuk meningkatkan volume dan kualitas trafik kunjungan melalui mesin pencari menuju situs web tertentu dengan memanfaatkan mekanisme kerja atau algoritma mesin pencari tersebut, yang menyebabkan tampilan urutan pertama adalah sebuah website yang dipercaya memberikan informasi yang bermanfaat (Nova Tri Cahyono, dkk. 2011). Disamping banyaknya data-data baru yang di crawler oleh google dan data-data lama yang masih disimpan oleh google, crawler merupakan suatu program atau script otomatis yang relatif simple, yang dengan metode tertentu melakukan scan atau perayapan ke semua halaman-halaman Internet untuk membuat index dari data yang dicarinya (Sulastri dan Eri Zuliarso. 2010). Sehingga, perlu adanya sistem yang bisa melakukan pengecekan secara otomatis ke mesin pencari dengan hanya memasukkan satu nama website,atau nomor telpon yang digunakan penipu dapat menampilkan data-data yang akurat dari hasil indexing google.

RegEx (Regular Expression) dari hasil grab google search dengan API (Application Programming Interface) merupakan suatu notasi fleksibel dan ringkas untuk mencari dan menggantikan pola teks, fungsi utama RegEx itu sendiri adalah mencari dan mengganti pola text, dengan adanya $\operatorname{RegEx}$ maka bisa mengetahui sebuah pola data yang akan diambil dari hasil grabbing. (Gregorius S Budhi, dkk. 2011). Sedangkan grabbing merupakan sebuah teknik untuk mengambil teks atau objek dari sebuah situs web dan kemudian dipindahkan ke situs web dimana program grab dijalankan. (Gregorius S Budhi, dkk. 2011).

Dengan menggunakan metode regex pada teknik grabbing yang dilakukan pada mesin pencari google mempermudah Cyber Crime Ditreskrimsus Polda DIY dalam mencari Information Gathering terhadap situs penipuan di Internet, RegEx (Regular Expression) merupakan suatu notasi fleksibel dan ringkas untuk mencari dan menggantikan pola teks, fungsi utama $R e g E x$ itu sendiri adalah mencari dan mengganti pola text, dengan adanya $\operatorname{RegEx}$ maka bisa mengetahui sebuah pola data yang akan diambil dari hasil grabbing. (Gregorius S Budhi, dkk. 2011). sedangkan grabbing merupakan sebuah teknik untuk mengambil teks atau objek dari sebuah situs web dan kemudian dipindahkan ke situs web dimana program grab dijalankan. (Gregorius S Budhi, dkk. 2011).

Sistem yang dimiliki oleh google akan melakukan penjelajahan dan pengambilan halaman-halaman web yang ada di Internet, hasil pengumpulan situs web selanjutnya akan diindeks oleh mesin pencari untuk ditampilkan pada halaman pencarian.

\section{LANDASAN TEORI}

Forensik memiliki arti "membawa ke pengadilan" istilah forensik adalah suatu proses ilmiah (didasari oleh ilmu pengetahuan) dalam mengumpulkan, menganalisa, dan menghadirkan berbagai bukti dalam sidang pengadilan terkait adanya suatu kasus hukum.Feri Sulianta (2008).

Regular Expression (REGEX) adalah konstruksi bahasa untuk mencocokkan teks berdasarkan pola tertentu, terutama untuk kasus-kasus kompleks. Selain itu, REGEX juga sangat manjur (powerful) terutama untuk proses penguraian kata (text parsing), Regular expression (regex) memungkinkan melakukan pencarian, substitusi, atau pemisahan string dalam kasus yang kompleks. Didik Dwi Prasetyo (2008).

API adalah Application Programming Interface yaitu sebuah layer yang berisi class-class yang sudah didefinisikan dan antarmuka pemrograman yang akan membantu para pengembang aplikasi dalam perancangan sebuah aplikasi, Arie Prabawati (2010).

Web grabbing dapat diartikan sebagai sebuah upaya untuk mengambil konten data, informasi atau konten dari sebuah halaman web tertentu. Grabbingkonten banyak dilakukan oleh blogger untuk mengambil data kurs nilai tukar dari halaman website Bank tertentu, jadwal penerbangan, kondisi cuaca, dan lainnya untuk kemudian ditampilkan pada halaman blog.Lorna Mitchell, dkk. (2011)

\section{METODE PENELITIAN}

Topik penelitian adalah menemukan metode untuk proses pelacakan kejahatan online dari hasil laporan masuk ke POLDA DIY. RegEX dari Grab Google Search Api 
digunakan sebagai metode pelacakan kejahatan online yang terindeks oleh google. Dengan ditemukannya metode dan sistem yang tepat dalam penanganan penipuan online berarti akan lebih mempercepat pemberantasan situs-situs yang digunakan untuk melakukan penipuan. Bagi masyarakat. metode pelacakan hasil lapor kejahatan online yang dilaporkan bisa secepatnya ditangani dan dapat mengetahui antara website terpercaya dengan website yang dibuat oleh penipu, sehingga masyarakat akan lebih berhati-hati terhadap penipuan.

Metode observasi dilakukan untuk mendapatkan gambaran proses pelaporan tindak kejahatan dan gambaran proses pelacakan yang saat ini yang dilakukan POLDA DIY. Untuk mendapatkan data bentuk-bentuk penipuan online maka metode interview dilakukan terhadap masyarakat yag pernah mendapatkan pesan penipuan.

\section{HASIL DAN PEMBAHASAN}

\section{A. Analisis Proses Pelaporan}

Tindak penipuan berupa peniriman sms yang berisi penipuan yang ditujuan ke calon korban. Isi dari pesan penipuan biasanya berlanjut pada proses menghubungi atau membuka alamat web yang palsu yagn harus dilakukan oleh calon korban. Pelaporan terhadap kasus penipuan online menggunakan website yang mengatasnamakan instansi masih dilakukan dengan cara bertatap muka. Pengecekan yang dilakukan oleh dinas kepolisian terhadap data yang dikirim oleh masyarakat yang terkena penipuan masih dilakukan dengan menggunakan cara mengunjungi website secara satu-persatu. Proses pelaporan ditreskrimsus Polda DIY dapat di gambarkan sebagai berikut:

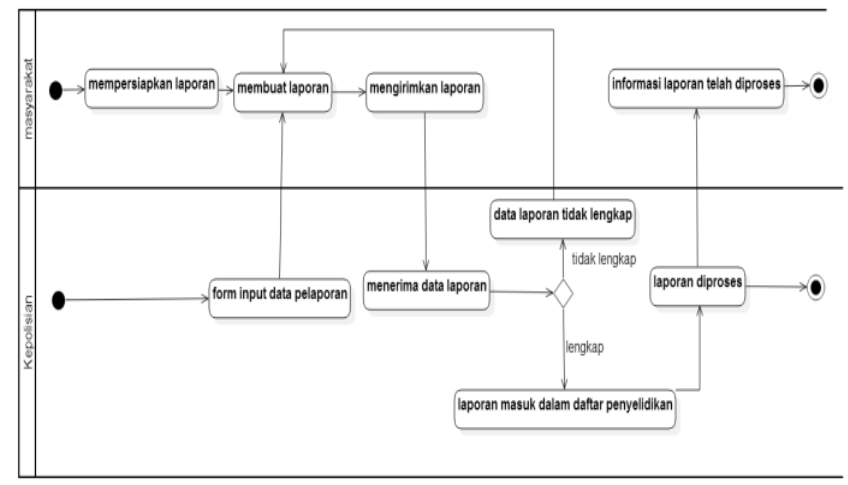

Gbr 1. Proses pelaporan saat ini

Masyarakat mengirimkan form laporan ke kepolisian dan akan dicek apakah data yang dilaporkan lengkap atau tidak. Proses akan dilanjutkan jika form dinyatakan lengkap dan masuk ke daftar penyidikan.

Setelah form pelaporan masuk ke daftar penyelidikan maka kepolisian akan melakukan proses pelacakan.

Dalam proses pelacakan manual, kepolisian menggunakan web broser dari mesin pencarian google untuk mendapatkan hasil data pencarian dan menyimpan data tersebut untuk kebutuhan penyelidikan. Dengan menggunakan sistem ini maka kepolisian harus memasukkan indeks pencarian satu persatu untuk mendapatkan data lengkap dari kemungkinan data yang sama yang dilaporkan beberapa masyarakat. Activity Diagram pelacakan secara manula terlihat pada gambar 2 berikut ini:

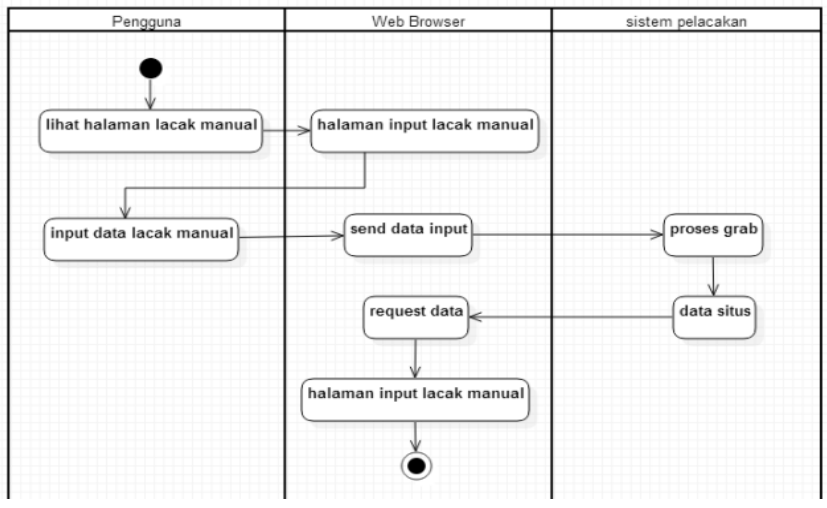

Gbr 2. Activity diagram proses pelacakan manual.

\section{B. Pembahasan}

Dari analisis proses bisnis saat ini, untuk kemudahan pelacakan maka dikembangkan proses pelacakan dengan menggunkan metode regex dan google api, alur sistem menggunakan metode regex (regular expression) dari grab google search api untuk sistem pelacakannya digambarkan sebagai berikut :

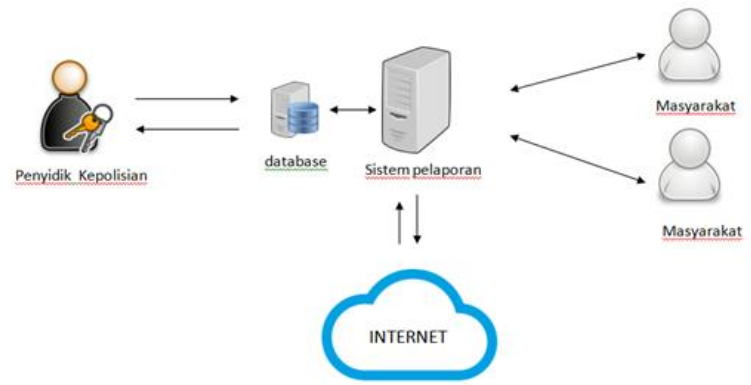

Gbr 3. Alur proses pelaporan dengan menggunakan sistem

Masyarakat melaporkan secara langsung pesan penipuan yang diterima melalui sistem pelaporan yang ada di kepolisian, pesan penipuan yang diterima sistem oleh penyidik kepolisian akan diproses pemecahan menurut pola yang telah ditentukan dengan menggunakan RegEx. Pada gambar. 4 merupakan contoh pesan penipuan yang akan melalui proses $\operatorname{RegEx}$., yaitu pemecahan konstruksi bahasa untuk mencocokkan teks berdasarkan pola tertentu, pola yang akan digunakan adalah kata dengan format alamat website, alamat email maupun nomor telepon yang akan menjadi indeks pencarian ke google API. 


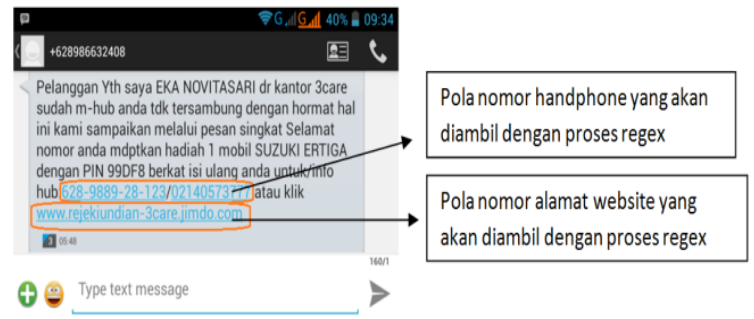

Gbr 4. Proses regex pada pesan penipuan

Dengan pola data hasil regex, dari contoh ditemukan adalah pola nomor handphone dan website maka sistem akan melakukan request kepada server google melalui api, yang kemudian data tersebut digunakan untuk pelacakan secara otomatis berdasarkan pola yang telah ditentukan yaitu terhadap website, nomor handphone atau email sesuai dengan hasil pola yang ditemukan di SMS. Pelacakan akan menghasilkan data dimana saja website atau nomor telepon tersebut digunakan oleh penipu, karena tidak sedikit alamat website atau nomor handphone digunakan untuk beberapa penipuan berbeda. Alur sistem request ke server google melalui api sebagai berikut

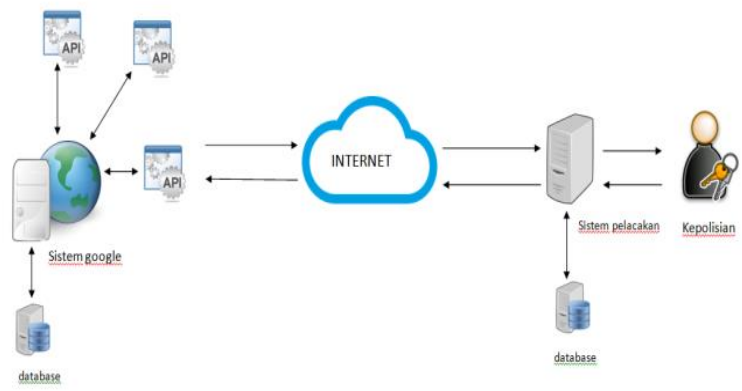

Gbr 5. Alur request ke server google melalui api.

Pelacakan Otomatis merupakan alur kerja sebuah proses request data pelacakan yang telah diinput pada server google untuk mendapatkan data pencarian sesuai dengan data inputan yang telah dikirim, yang kemudian data hasil request dari server google dapat ditampilkan dalam sistem pelacakan. Proses pelacakan otomatis tergambarkan dengan activity sebagai berikut

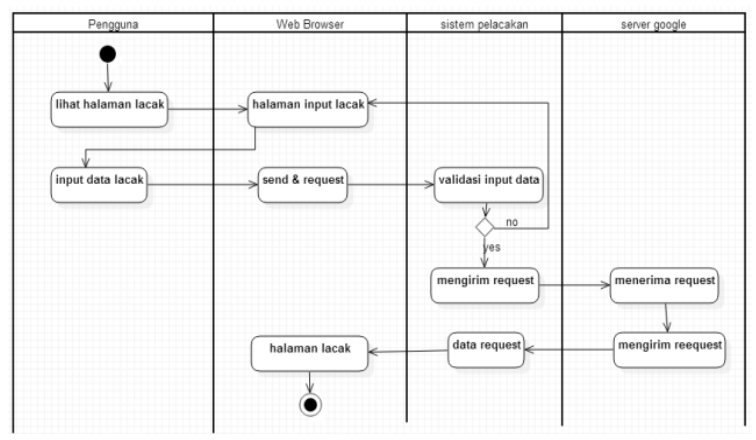

Gbr 6. Activity diagram sistem pelacakan otomatis.

Untuk membantu proses pelacakan maka dibangun sistem sebagai alat bantu masyarakat untuk proses pelaporan. Hasil pelaporan dari masyarakat dengan sistm akan diproses secara forensik digital untuk menemukan situs yang digunakan untuk penipuan. Gambar 7 adalah halaman home yang digunakan untuk masyarakat melaporkan penipuan.

Pelacakan dilakukan dengan berdasarkan keyword, alamat website, nomor handphone dari hasil laporan yang dikirimkan oleh masyrakat. Gambar 7 merupakan interface home pada aplikasi pelacakan yang berfungsi sebagai pintu awal masyakar melaporkan kejahatan online melalui sistem. Laporan inilah yang akan menjadi data awal proses digital forensik kejahatan melalui online.
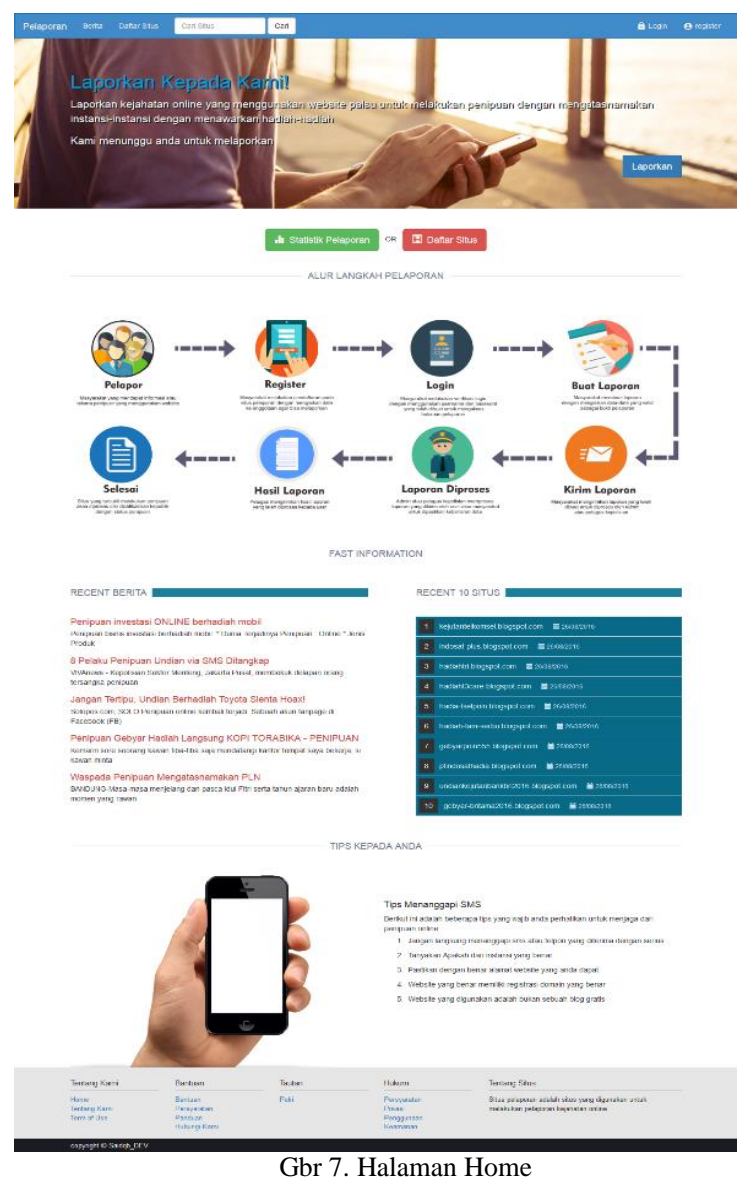

Hasil dari pelacakan otomatis yang dilakukan oleh sistem akan di simpan oleh kepolisian dalam daftar situs sebagai bahan untuk proses penyelidikan. Yang akhirnya situs-situs penipuan akan dipublikasikan oleh kepolisian kepada masyarakat. Data yang akan ditampilkan bersangkutan dengan situs antara lain jumlah data laporan yang masuk berkaitan dengan alamat situs yang dimaksud. 


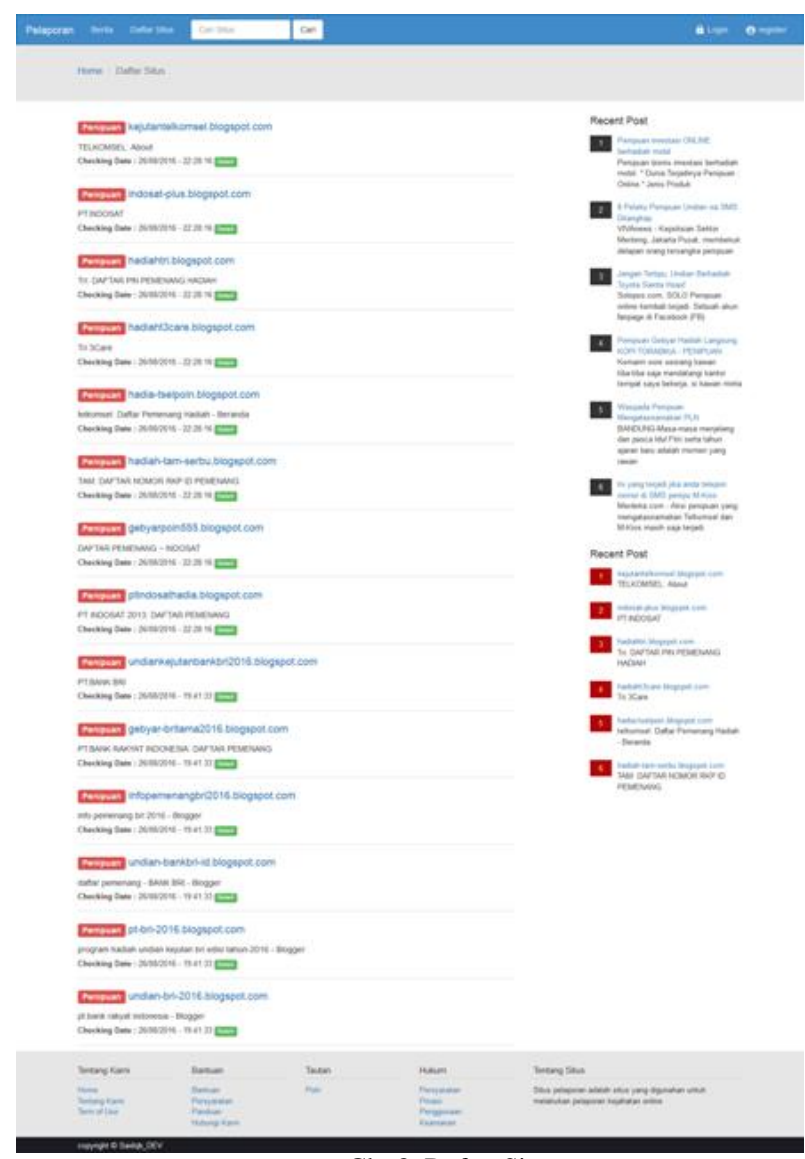

Gbr 8. Daftar Situs

\section{KESIMPULAN}

Dengan sistem pelacakan dengan menerapkan grab google search menggunakan metode RegEx pada website dan blog dengan keyword, website, nomor handphone yang digunakan untuk melakukan penipuan dari hasil laporan yang dikirimkan oleh masyarakat dapat mempercepat proses pencarian situs penipuan yang di-index oleh google. Dan mempercepat pemberantasan situs-situs yang digunakan untuk melakukan penipuan.

Dari informasi dari kepolisian tentang hasil pelacakan situs-situs yang digunakan untuk penipuan, masyarakat dapat mengetahui antara website terpercaya dengan website yang dibuat oleh penipu, sehingga masyarakat akan lebih berhati-hati terhadap penipuan.

\section{REFERENSI}

[1] Didik Dwi Prasetyo. 2008. 101 Tip \& Trik Pemrograman Php, PT Elex Media Komputindo, Jakarta

[2] Diminikus Juju dan Feri Sulianta. 2010. Hitam Putih Facebook, PT Elex Media Komputindo, Jakarta

[3] Feri Sulianta. 2008. Komputer Forensik, PT Elek Media Komputindo, Jakarta

[4] Lorna Mitchell, dkk. 2011. PHP MAster: Write Cutting-edge Code, United States, SitePoint
[5] Jia Liu and Husheng Liao. Intersection Checking for Regular Expressions Based on Inference System, Beijing University of Technology, Beijing, China. 2015.

[6] Nova Tri Cahyono, dkk. Penerapan Teknik Seo (Search Engine Optimization) Pada Blog (Studi Kasus: Nova13.Com), Teknik Informatika, Institut Sains \& Teknologi AKPRIND Yogyakarta. 2011.

[7] Putri Ratnasari. Mekanisme Penegakan Hukum Terhadap Tindak Pidana Penipuan Melalui Media Eletronik. 2015.

[8] Saut Manatar Tua Hasugian. Kendala Polda Diy dalam Mengungkap Tindak Pidana Penipuan Melalui Internet D Provinsi Daerah Istimewa Yogyakarta, Yogyakarta, Ilmu Hukum Universitas Atma Jaya Yogyakarta.2013.

[9] Sutji Decilya.. Polisi Tangani 600 Kejahatan Online Per Tahun. Tempo, Jakarta, 15 mei 2013. 